\title{
PERFORMANCE PROCESS AND CONTEMPORARY PRACTICES IN MOROCCAN LOCAL AUTHORITIES: CASE STUDY OF URBAN MUNICIPALITY
}

\author{
Nouha AMRANI®1, Ilona SKAČKAUSKIENĖ®2* ${ }^{*}$, Mohamed HEMMI ${ }^{3}$ \\ 1,3 Department of Management, Faculty of Economics and Management Sciences, USMBA, Fez, Morocco \\ ${ }^{2}$ Department of Management, Faculty of Business Management, Vilnius Gediminas Technical University, \\ Vilnius, Lithuania
}

Received 28 February 2021; accepted 1 April 2021

\begin{abstract}
Purpose - the aim of this paper is to shed light on a contemporary issue related to performance practices and approaches in Local Authotities (LA) while studying the case of an urban municipality.

Research methodology - the methodology applied is a documentary analysis of the Municipal Action Plan (MAP) and semi-directive interviews with territorial executives and elected officials who contributed to the MAP's elaboration.

Findings - the results obtained show that the municipality adopts a developed performance approach similar to what has been applied in public institution according to the organic law of Finance (LOLF).

Rresearch limitations - the results cannot be generalized because of choosing a single case study. In addition, some questions in the interview contain technical words that the interviewee does not master, which also risks biasing our results.

Practical implications - on the theoretical level, these results can be the starting point for future research in such issues. On the practical level, the results obtained sensitize territorial responsible about the importance of performance approach and inspire them to implement it.

Originality/Value - this study in among the rarer that attempted to understand the process of performance approach in LA, especially in Moroccan context, where most research tends to deal with problems related to the budget and financial aspect which reflects originality and novelty.
\end{abstract}

Keywords: public performance, new public management, results-based management, Local Authorities, Municipal Action Plan, Organic Law of Finance.

JEL Classification: M10, M16.

Conference topic: Contemporary Organizations Development Management.

\section{Introduction}

All over the world, public organizations have gone through a critical phase due to the succession of crises and socio-economic problems on the one hand and the domination of privatization and bureaucracy as a management logic on the other. Since the 1980s, profound changes have been observed that aim at restructuring such situations through the modernization of public management. The multiple reforms are undertaken, although they differ from one country to another, share common goals and objectives that revolve around performance.

As a result of the profound changes that have marked the public sphere, the concept of performance, which was frequently used in the private sector, has increasingly become the ultimate goal of reforms carried out in public organizations, whether at the central or local level. This can be explained by the development of a new managerial culture recognized by New Public Management (NPM), which seeks to correct the anomalies stemming from the old management models by moving from a purely bureaucratic administrative model to managerial model, more flexible, focused on results and inspired by private management (Bačlija, 2012). This transposition initially concerned central governments and government agencies, and gradually became relatively common in local governments (Bouckaert \& Halligan, 2008).

*E-mail: ilona.skackauskiene@vilniustech.lt

(C) 2021 Authors. Published by Vilnius Gediminas Technical University. This is an open-access article distributed under the terms of the Creative Commons Attribution (http://creativecommons.org/licenses/by/4.0/) License, which permits unrestricted use, distribution, and reproduction in any medium, provided the original author and source are credited. 
In Morocco, despite the reforms undertaken, local authorities are still wading through various organizational problems: financial scandals in the awarding of public contracts, financial bankruptcies, the inefficiency of local public aid, wastefulness, insufficient local services due to the inconsistent with the needs of local actors, or organizational and managerial dysfunctions (Amrani et al., 2021). Besides, the rise of social and economic demands from citizens make the introduction of the performance approach in LA an essential target. However, the LA don't have a formalized framework for initiating performance management like organic law of Finance (LOLF), which concerns structures under the authority of the State, such as public administration.

According to the LOLF, public institutions are required to present annual performance reports using an approach that shows programs that are broken down into projects or actions supported by objectives and evaluation indicators grouped according to the following typology: Socio-economic effectiveness, management efficiency, and quality of service. If the previous approach is generalized in ministerial departments, this makes us ask the question about the situation of LA where the process is voluntary and practices differ from one level to another. Hence the importance of the following question: what are the specificities of performance practices adopted by LA, and how do they differ from those adopted by other public institutions?

The objective of this paper is to highlight the contemporary practices and approaches of performance in LA while studying the case of an urban municipality. To do this, we adopted a documentary analysis approach of the Municipal Action Plan (MAP) of the municipality concerned, then we called upon semi-directive interviews with some territorial executives and elected officials who contributed to the elaboration of the MAP.

To provide some answers to the initial question, the paper begins with the literature review about LA's public sector performance. Then we tackle the reforms and specificities of the performance approach in the Moroccan context. Finally, we present a case study on performance practices and the approach adopted by an urban municipality.

\section{Theoretical framework on performance}

As in previous studies that have looked at framing the concept of performance in different areas, it is clear that the concept is difficult and complex to define. As defined by several authors, performance refers to a triptych composed of objectives, means, and results (Issor, 2017; Salgado, 2014, 2013; Notat, 2007; Bourguignon, 1995). For some authors, the definition of performance may be limited to a combination of effectiveness and efficiency (Marion et al., 2012). However, due to the multiplicity of definitions and their overlap, performance with its different components (definitions, measurement, evaluation, indicators, etc.) is still debated either because they are too general or because they are adopted uncritically in inappropriate contexts.

In the public sector, these findings can only be confirmed given the nature and specificities of the context (Maurel et al., 2014) where objectives are not well defined, and resources are limited. Despite the attempts and initiatives aimed at adapting it, the notion of public performance lacks precision and does not cover a set of common practices based on an explicit and recognized framework. As a result, it remains vague and ambiguous because it means different things to different actors. According to this perspective, it is specified that for LA, due to the multiplicity of territorial levels (regions, provinces, prefectures, and municipalities) and because of the diversity of actors (territorial and elected officials) the perception of performance can't be the same (Walker \& Andrews, 2015). Elected officials have a political orientation to satisfy citizens in order to gain their trust and reserve a place for the next mandate. Therefore, their performance is summed up by the quality of the service provided to users. On the other hand, the territorial executives have a managerial rather than political orientation which is expressed by their full motivation when it comes to a reform action with the modernization of the management system and this can be explained by their positioning as responsible managers on the management of the organization.

Adopting a performance approach in local authorities means highlighting what has been undertaken by LA in terms of performance research, then supporting them by making the necessary and useful corrections (Zahed, 2017). This approach aims to give the actors (managers and elected officials) considerable leeway so that they could accomplish their functions, subject to accountability for the results obtained in relation to the objectives set out beforehand and the means implemented. The performance approach has some similarities with management control and public policy evaluation; therefore, it is considered as an essential element that deserves to be studied in detail.

On this basis, the performance approach in LA can then take on different meanings: first of all, it is an objective for the management of LA that aims to implement a contemporary management system, and also a means of managing LA that enables the organizations to achieve their objectives.

\subsection{Performance approach as an objective}

The quest for performance is a commitment that most OECD countries have made through reforms in the early 1990s. Several initiatives have been deployed in this regard: Public service agreements (PSAs) in the United Kingdom, Reports on Plans and Priorities (RPPs) in Canada, "Portfolio budget statements" (PBSs) in Australia, "Loi organique relative à la loi de finance" (LOLF) in France, Netherlands and Morocco. Despite the diversity in the titles, these 
programs aim to implement annual performance reports and to present an assessment of public action. These programs rely on changing the logic of management in the public sector to take into account the effectiveness and efficiency of public services.

The importance of the LOLF is justified by its adoption in different contexts. Its ambition is to introduce a performance approach within public administrations while aiming at better use of public spending and improving the effectiveness of public policies, particularly in a context marked by the scarcity of public funds (Calmette, 2006). Moreover, its application goes beyond the budgetary aspect since it cannot be reduced to mere budgeting. Among other things, the LOLF contribute to draw the lines of a new public governance oriented towards evaluation and the search for performance by relying on instruments and tools inspired by private management, such as management control and audit, in order to orient management methods towards a logic of results.

Performance as a management objective has not been neglected by local authorities despite the absence of a formalized framework similar to that of the LOLF. Local dimensions, including population size, geographical location, and financial health, are important determinants in understanding the need for a performance approach. This heterogeneity at the local level has materialized in significant advances in performance by some communities and by others that have not taken steps in this direction. Generally, the biggest LA are those that express the need in this approach by setting up objectives and implementing indicators that act as true barometers to measure the performance of local management (Zahed, 2017).

\subsection{Performance approach as a means}

The performance approach is an objective for public authorities to ensure the aims of policies, but also a means for managers to implement a modern management approach that responds to organizational needs and specificities to deal with environmental changes and requirements.

Results-based management, also called performance-based management (Newcomer \& Caudle, 2011), is a mode of management that has its origins in the NPM (Proulx \& Machiavelli, 2005) and has been applied in various OECD countries since the 1990s (Mazouz et al., 2012). It aims to achieve the effectiveness and efficiency of public action by granting managerial autonomy and considerable leeway to managers while strengthening the control system (Bezes, 2005). These changes in public management give managers more freedom, but in return, they increase their accountability for results. As a result, results-based management can be seen as a form of ex post management control based on a contractual approach involving the principal (managers) and the executor (administrators).

The research conducted by van Helden and Johnsen (2002) shows that the implementation of results-based management in an organization depends on two essential criteria: 1) the level of uncertainty between objectives and means, and 2) the degree of ambiguity of the objectives set. Table 1 describes the possible combinations.

In the logic of transposing the performance approach to the public sector, it is legitimate to ask what about LA concerning results-based management? Saldanha (2002) states that results-based management has become popular in LA because it clarifies the mandates of elected officials, specifies the roles of territorial leaders and managers, and sets results according to the performance expectations of citizen-users. It does this by requiring performance reporting, linking budget al.ocation to the delivery of results, encouraging continuous improvement and performance analysis, and involving meritocracy in human resource management. However, the degree of its integration into local government differs from one country to another. In some countries, such as England and Sweden, some laws require LA to follow this approach, while in others, such as Morocco and France, this approach is desirable in the absence of a legislative framework that advocates its application in this specific context.

Because citizens, as well as the different actors, have become increasingly aware of the quality of services (Welch, 2004), LA have begun to deploy initiatives and reforms to implement results-based management as a management system that ensures the efficiency of public spending, streamlines and simplifies public spending procedures, and strengthens budget deconcentration to promote local management that meets citizens' expectations, with the ultimate goal of improving performance. Furthermore, Kusek and Rist (2004) state that results-based management has been

Table 1. Results-based management and criteria for implementation (source: van Helden \& Johnsen, 2002)

\begin{tabular}{|c|l|l|}
\hline \multirow{2}{*}{ Ambiguity goals } & \multicolumn{2}{|c|}{ Uncertainty on means-ends relationships (Technology) } \\
\cline { 2 - 3 } & \multicolumn{1}{|c|}{ Low } & \multicolumn{1}{|c|}{ High } \\
\hline \multirow{2}{*}{ Low } & $\begin{array}{l}\text { I } \\
\text { Input or output control } \\
\text { Performance-based management is optional }\end{array}$ & $\begin{array}{l}\text { II } \\
\text { Output control } \\
\text { Performance-based management is likely }\end{array}$ \\
\hline High & $\begin{array}{l}\text { III } \\
\text { Behaviour (rule) control } \\
\text { Performance-based management is unlikely }\end{array}$ & $\begin{array}{l}\text { IV } \\
\text { Decoupling clan control and political control } \\
\text { for symbolic reasons) }\end{array}$ \\
\hline
\end{tabular}


introduced in LA for a useful evaluation of results and better implementation and communication of programs and projects. Nevertheless, the introduction of such an approach in LA requires a long-term effort because it faces certain difficulties relating to the will of political leaders, organizational change, and the necessary means, whether in terms of the qualifications of human resources or the availability of financial resources.

However, according to Pazvakavambwa and Steyn (2014), the introduction of reforms is often resisted because it is difficult for individuals in organizations to change their culture. Thus, Rubakula (2014) asserts that politicians have not succeeded in translating these reforms leading to performance-based management into reality because they go beyond the specificities of the local context when transposition proves less useful, hence the importance of being part of a logic of appropriation. Moreover, the reluctance to decentralization impacts, among other things the resources mobilized for the implementation of such an approach, which leads to its failure.

Therefore, the implementation of the performance approach requires several prerequisites to guarantee its success. Namely, a process that takes the major orientations of the public authorities and the national assembly down to the smallest level of the administration, which represents the interface with the user (Zahed, 2017).

The evolution of theoretical contributions to public performance can be explained by the growing need for this approach practically.

In this section, we developed how the performance concept has evolved from private to public organizations and how a performance approach has been transposed to the local public context given its particularities and obstacles. We have also pointed out that the performance approach can take different positions:

- It is seen as an objective of public management at this level we have referred to what is meant by performance management, which aims at optimizing performance through the reforms undertaken, which differs from one country to another and which we have chosen to represent by the LOLF model given its wide application.

- It is seen as a means of public management, i.e., as a foundation of management that enables the achievement of objectives. From this perspective, we have treated performance-based management as a managerial innovation in LA.

\section{Performance in Moroccan LA: A chronology of reforms}

According to the Moroccan constitution, LA is defined as a legal entity under public law that exercises certain powers over its territory as a constituency, which are devolved to it by the State. They are determined by three levels: regions (12), provinces and prefectures (75), and finally municipalities (1503). They constitute the essence of the vision of territorial development and contribute to the restructuring of State action. On the other hand, because of their proximity, and despite the weaknesses that may hinder their actions, LA is considered as valid interlocutors because they are best placed to know and assess needs and identify local priorities (El Moujahid, 2019). The reforms process in LA is presented in several stages (Figure 1).

- The first phase is about the initialization of decentralization between 1959 and 1976, marked by a first administrative division in 1959 and the adoption of the first municipal charter in 1960, completed by a charter of 1976. As a result, the role of the municipality was extended through their participation in local development.

- The second phase, between 1990 and 2009, is a phase of acceleration of decentralization that came with its share of reforms: the law relating to the organization of the region in 1997 and launches the quest for new local management practices, the municipal charter of 2002 and law $n^{\circ} 79-00$ relating to the organization of prefectural and provincial authorities and established new rules of good territorial governance based on managerial autonomy.

- The third phase, which lasted from 2010 to 2015 , marked by a revision of the constitution in 2011, an increase in the power of the region with the launch of advanced regionalization in 2015, and finally, the promulgation of organic laws: 111-14 on the regions, law 112-14 on the prefectures and law 133-14 on the communes.

The 2011 constitution institutionalized these reforms by devoting a whole chapter to the rules of good governance relating to the functioning of public administrations and LA. From now on, it has been considered as a frame of reference defining the principles guiding the territorial organization and outlining local management according to three principles:

- The principle of free administration allows LA to freely carry out their missions within the limits of their competencies. Through this principle, the responsibility of local and regional authorities increases significantly: the possibility to administer themselves freely, without being subject to undue constraints, and without interfering with the legislative, executive, and judicial powers. On this basis, the presidents have the leeway to enable them to manage their affairs successfully.

- The principle of subsidiarity, which stipulates that LA may share common powers and responsibilities with the State, provided they are transferable by the latter.

- And finally, the principle of cooperation and partnership, which is based on solidarity between the different territorial levels (municipalities, province, and prefecture), whether at the national or international level, allows for synergy in the achievement of objectives. 


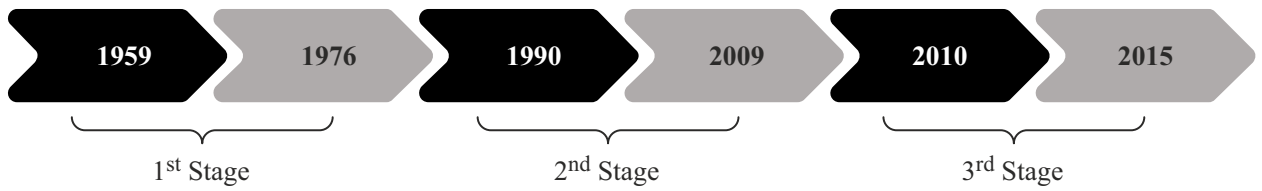

Figure 1. Reform's process for Moroccan LA (source: created by authors)

The year 2015 marked a turning point in the history of local government reform processes because of the events that characterized the year. First of all, the adoption of advanced regionalization, a Moroccan experience inspired by European models (France, Italy, Spain, and Germany), which aims at delegating powers from the central government to LA in administrative, economic, or political fields. Its adoption has provided unprecedented opportunities for the management of LA, as it has promoted the idea of performance-based management.

Advanced regionalization was accompanied by a new administrative division that reduced the number of regions from 16 to 12 . The objective is to group regions that are close according to several criteria to optimize financial resources. Also, the legal framework has been strengthened by the enactment of three organic laws relating to LA: Law 111-14 relating to the regions, Law 112-14 relating to prefectures, and Law 133-14 relating to municipalities. They aim to provide greater clarity on the functioning of LA concerning their own powers and those shared with the State, financial resources, rules of governance relating to the proper functioning of free administration, control of the management of development funds and programs, evaluation of actions and accountability. The purpose of these new provisions is to orient local public management towards performance goals while applying the principles of results-based management.

\section{Performance approach in local Moroccan authorities: ongoing project}

With the promulgation of the organic law relating to the finance law (law No 130-13), public institutions are required to produce annual performance reports by an approach dictated by the law. This law aims to revise the management of public affairs, particularly about the budgetary aspect, by moving from a logic of means (a legal and technical approach to the functioning of the administration) to a logic of results (an approach that favors a managerial culture at the service of citizens) as shows Table 2 .

The LOLF is, therefore, the legal framework that comes to anchor and formalizes results-based management, as well as to generalize and unify the performance approach in public organizations. In principle, results-based management should satisfy four imperatives (Mazouz \& Leclerc, 2008): organizational, managerial, adaptive, and evaluation, which the Moroccan LOLF has translated into four main areas: multi-year programming of public spending, globalization of credits, contractualization, and evaluation (Rachid \& Lahmouchi, 2019).

In addition to the budgetary approach, the LOLF sets out the performance approach to be followed by the various ministerial departments. It is a steering mechanism for administrations oriented towards measuring and improving the effectiveness of political programs. According to this perspective, for each program, a performance approach is defined consisting of three steps: the program strategy, the performance objectives that stem from this strategy, and the performance indicators that measure the achievement of these objectives in different dimensions in terms of effectiveness, efficiency, and quality of services and expected results (Figure 2).

This approach is likely to increase transparency by informing all stakeholders (citizens, users, taxpayers) about public policy priorities, guiding the organization's work, and reporting on the results of the actions deployed in the context of annual reporting (Annual Performance Reports) (Huteau, 2008).

Table 2. From the logic of means to the logic of result (source: Haddad, 2011)

\begin{tabular}{|l|l|}
\hline Conventional budget system & New Approach to Public Management \\
\hline Average budget & Budget by program \\
\hline Annual Perspective & Multi-year perspective \\
\hline Operating Budget & Unification of the budget formulation process \\
\hline Little leeway in resource allocation & Flexibility in the allocation of resources in the medium term \\
\hline Means Based Management & Managing for Results \\
\hline Post-expenditure (ex-post) review of government action & $\begin{array}{l}\text { Existence of performance indicators defined before the public } \\
\text { intervention (ex-ante) }\end{array}$ \\
\hline $\begin{array}{l}\text { Weak link between government strategy and } \\
\text { budget allocations }\end{array}$ & $\begin{array}{l}\text { Existence of a link between national priorities and sectoral } \\
\text { objectives }\end{array}$ \\
\hline
\end{tabular}




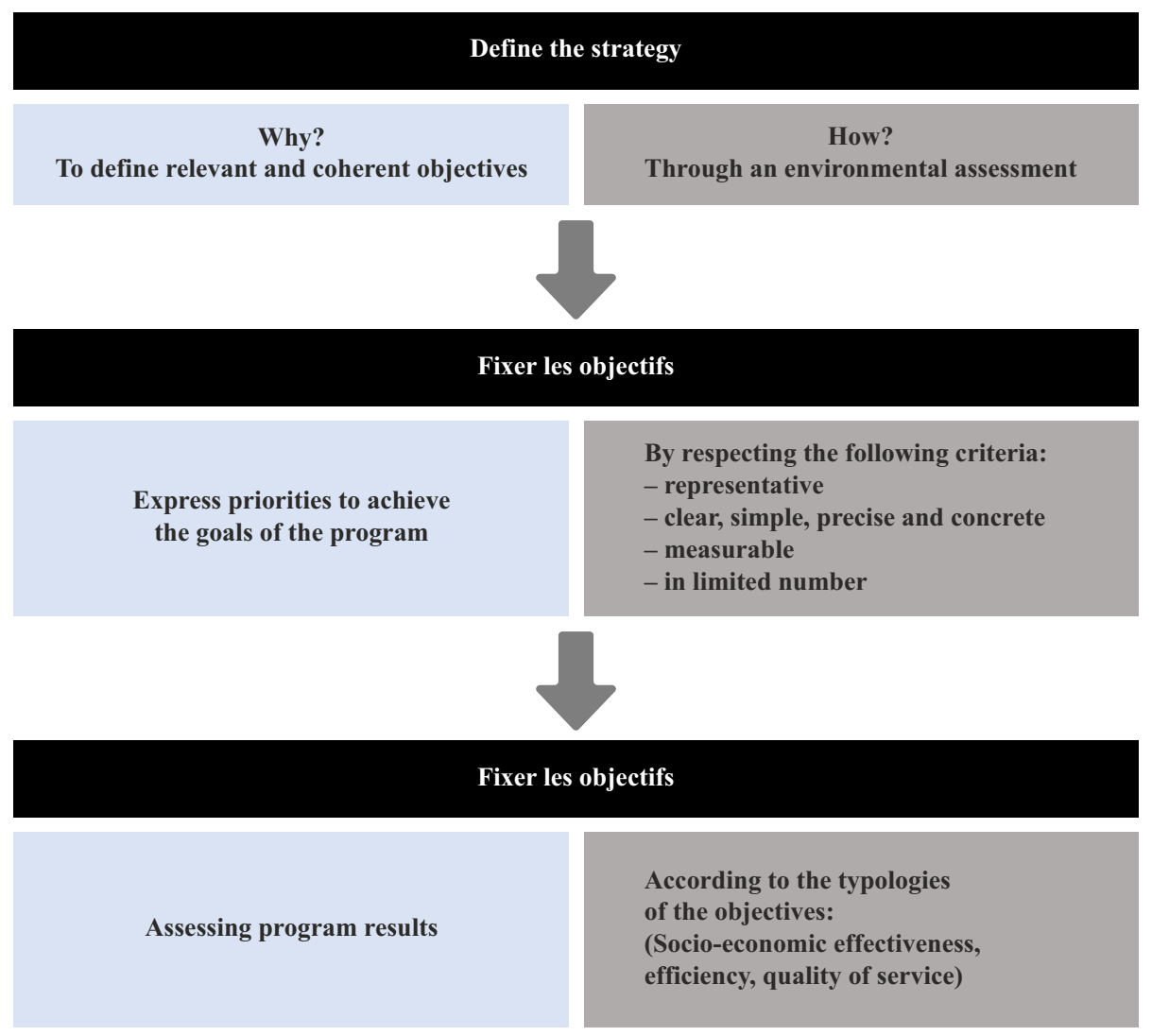

Figure 2. The performance approach dictated by the LOLF in Morocco (source: created by authors)

While at the central level, public administrations have already been imbued with a practical, standardized, and generalized framework for managing their performance, at the local level, a formal performance management framework does not exist. Several researchers are beginning to question whether or not it is possible to transpose such an approach to LA (Huteau \& Arthuis, 2006; Zahed, 2017; Rubakula, 2014). The performance approach In Moroccan LA, is in progress because of the difficulties encountered during its implementation. To understand these difficulties, an interview guide was conducted to different municipalities (four urban, four rural) by contacting elected representatives and territorial managers about the following axes: (1) management system (organisational structure, objectives, human resources), (2) performance aspects (practices, process, perception of stockholders/ actors, indicators). The following Table 3 shows some statements made by interviewees.

According to the above statements, the constraints to the implementation of a performance approach can be grouped into three categories: firstly, external constraints related to the environment represented by the country's institutional, political, legal, and economic framework, which play an important role in the dynamics of change. Territorial officials claim the incompatibility of certain legal clauses with reality, which slows down the reform process. Let al.ne the contribution of stakeholders (citizens, users, elected officials, and administrative officials) who can, in some cases, be an obstacle to the success of the process.

In addition, the organizational constraints relating to the effect of size and the means available for the development of a performance approach. Indeed, the interest and complexity of the approach differ from a municipality to another according to its nature (urban or rural) because the difficulty increases with each increase in population. The same applies to the resources mobilized, particularly financial and human resources, which should, in principle, make it possible to support communication, organization, planning, involvement, and participation of stakeholders. Whereas the majority of municipalities lack financial resources and appropriate profiles in terms of quantity and quality as indicated by the Economic, Social and Environmental Council (ESEC, 2013): 23\% of municipality councilors have the higher level, $31 \%$ have the secondary level, $25 \%$ the primary level, and $21 \%$ have no schooling.

And finally, the technical constraints determining the deviances that result from the transposition of the LOLF type performance approach in LA. Beginning with the objectives which are not clear, and which are difficult to set up because of the multiple and variable competencies of the municipalities as well as the nature of the projects to which they commit themselves, consequently, the whole logic of the approach will be distorted including the definition of indicators and the measurement of performance. This poses difficulties when moving from the evaluation and perfor- 
Table 3. Constraints of implementation performance approach in municipalities concerned according to the statements of the actors (source: created by authors)

\begin{tabular}{|c|c|c|}
\hline Elements of answers & $\begin{array}{l}\text { Position of the } \\
\text { interviewee }\end{array}$ & Constraints identified \\
\hline $\begin{array}{l}\text { "Until now, LA are structures that lack planning, forecasting, } \\
\text { and a formal management system". }\end{array}$ & $\begin{array}{l}\text { Territorial executive } \\
\text { in a rural community }\end{array}$ & Lack of formal management. \\
\hline $\begin{array}{l}\text { "The lack of communication between administrators and } \\
\text { elected officials and the lack of coordination between the } \\
\text { different services at the local level are among the problems } \\
\text { that hinder the smooth running of local communities". }\end{array}$ & $\begin{array}{l}\text { Service manager of an } \\
\text { urban municipality }\end{array}$ & $\begin{array}{l}\text { Rigidity about the flow of information } \\
\text { between the different components. }\end{array}$ \\
\hline $\begin{array}{l}\text { "The majority of municipalities in Morocco suffer from a } \\
\text { lack of funding, insufficient human resources, lack of quantity } \\
\text { and quality (qualifications), an information system that is not } \\
\text { effective and problems with the management system". }\end{array}$ & $\begin{array}{l}\text { Service manager of an } \\
\text { urban municipality }\end{array}$ & $\begin{array}{l}\text { Lack of funding, need for qualified } \\
\text { human capital, lack of modern } \\
\text { management tools. }\end{array}$ \\
\hline $\begin{array}{l}\text { "The failure of the management system in the municipality } \\
\text { has repercussions on the missions of the president who is } \\
\text { faced with a dilemma: to manage the administrative affairs of } \\
\text { the municipality or to concentrate on development projects } \\
\text { which are in principle the fundamental object of his mission". }\end{array}$ & $\begin{array}{l}\text { Elected in a rural } \\
\text { community }\end{array}$ & $\begin{array}{l}\text { Confusion between tasks and } \\
\text { accountability: who does what? }\end{array}$ \\
\hline $\begin{array}{l}\text { "As part of the new reforms undertaken, new laws have been } \\
\text { enacted that go far beyond the reality on the ground in terms } \\
\text { of resources". }\end{array}$ & $\begin{array}{l}\text { Elected in a rural } \\
\text { community }\end{array}$ & $\begin{array}{l}\text { The incompatibility of some legal } \\
\text { clauses with reality. }\end{array}$ \\
\hline $\begin{array}{l}\text { "Performance is not limited to organizational and measurable } \\
\text { variables. The performance of a municipality also depends } \\
\text { on the degree of citizen satisfaction with the services and } \\
\text { programs offered". }\end{array}$ & $\begin{array}{l}\text { Elected in an urban } \\
\text { municipality }\end{array}$ & $\begin{array}{l}\text { The difficulty of measuring } \\
\text { performance of municipalities because } \\
\text { it depends on qualitative variables } \\
\text { such as citizen satisfaction. }\end{array}$ \\
\hline $\begin{array}{l}\text { "No idea about the provisions of the LOLF applied in } \\
\text { the different ministerial organizations. What we do at the } \\
\text { management level is mainly to follow the orientations of } \\
\text { the supervising ministry and to follow the provisions of the } \\
\text { organic laws relating to LA". }\end{array}$ & $\begin{array}{l}\text { Territorial executive } \\
\text { in a rural community }\end{array}$ & $\begin{array}{l}\text { Managers are unaware about the } \\
\text { LOLF and its contribution in public } \\
\text { performance. } \\
\text { Application of the laws without } \\
\text { innovation and diligence. } \\
\text { NPM is not even in the embryonic } \\
\text { phase. }\end{array}$ \\
\hline $\begin{array}{l}\text { "To tell the truth, our municipality is not in a position to apply } \\
\text { new management practices (NMP), in particular, to apply } \\
\text { a real performance approach due to the lack of necessary } \\
\text { resources". }\end{array}$ & $\begin{array}{l}\text { The territorial } \\
\text { framework of an } \\
\text { urban municipality }\end{array}$ & $\begin{array}{l}\text { Size and culture are determining } \\
\text { variables for the implementation of a } \\
\text { performance approach. }\end{array}$ \\
\hline
\end{tabular}

mance measurement phase to that of true performance-based management (Bouckaert \& Halligan, 2008). From the above, despite the obstacles detected, some of these communities have already opted for this approach to provide a real boost to local management. From this perspective, we chose to study the case of one urban municipality selected among the 8 municipalities we visited during our exploration study.

\section{Context and methodology adopted}

The municipality of Tangier is an urban municipality located at the extreme north-west of the country and covers an area estimated at $128 \mathrm{~km}^{2}$. It includes four districts, and its population is 1065601 inhabitants according to the 2015 census. Since 2016, the municipality has undergone a remarkable evolution thanks to the adoption of a development program enhanced by investments in the following areas: urban planning, social, economic, and cultural. About its management system, the municipality has seen a rise in power with the adoption of some private management tools, namely the SWOT matrix for good control of its external environment (strengths, weaknesses, opportunities, and threats), the POTI technique (Process Organization Information Technology) which enables the management of the future and the organization of programs, the use of the dashboard for performance management and the successful program mapping which is a repository of good management practices to drive change and align programs and projects with the strategy. These different tools allow the main practices of the NPM to be consecrated. Despite these advances, the municipality continues to record dysfunctions due to a succession of deficits caused by an imbalance between budget forecasts and actual revenue. Based on these observations, it is legitimate to question the municipality's commitment to the performance approach.

The choice of the Tangier municipality is justified by its positioning among the most developed urban municipalities in terms of managerial and organizational reforms and in terms of the human capital that makes it up. Thus, it 
considers itself among the pioneers in Morocco who tried to introduce the NPM and its principles in the territorial context. In the same vein, the municipality of Tangier was chosen to be the subject of our study because of the scarcity of municipalities that have a formal document describing their performance approach on the one hand, and the other hand because it was selected among the 103 pilot municipalities to participate in the "support program for improving the performance of Moroccan municipalities". This is a project carried out in partnership between the Directorate General of LA, the World Bank, and the French Development Agency for a period of 5 years (20192023). The objective is to establish a performance-based framework that will enable municipalities to structure their financing and management systems to preserve and strengthen the quality of public services and to take advantage of inter-municipal synergies in this area.

The objective of this study is to understand the performance practices in Moroccan municipality and to compare them with those adopted by ministerial departments. It is part of an exploratory approach that has the advantage of providing the researcher with the possibility of having innovative results and/or creating new theoretical articulations (Thiétart, 2014). To do so, we have opted for a qualitative methodological approach generally used to study phenomena in their natural setting with the use of interviews, archive analysis, observations, and surveys and by attempting to interpret phenomena in terms of the meanings provided by the actors (Denzin \& Lincoln, 2005).

Following this logic, the data collection process was based on the documentary analysis approach. Then, we used the information and data contained in the MAP as well as the various reports published by the municipality on its website. Also, this process was supplemented by a few interviews with officials: local executives and elected officials who had contributed to the development of the MAP (Table 3). These interviews are essential sources of information for the case studies (Yin, 2009), which will allow us to request additional explanations and clarifications to the available documentation. As Gagnon (2012) states, a single case study is recommended for a previously unexplored problem or phenomenon. It is a preferred research strategy for studying a little-known or particularly complex phenomenon, discovering new meanings, refining an innovative conceptualization, or transferring conceptualizations from one theoretical or practical context to another (Prévost \& Roy, 2015). It is based on this assertion that we have chosen to opt for a single case study involving a single stratum to enable us to apprehend the performance approach in LA, which is always ambiguous in the absence of a frame of reference, through a determination of the similarities and divergences of the approach between the local and central levels.

\section{Result and discussion}

The MAP, as indicated in article 78 of the organic law, is a document prepared by the president of the municipality in coordination with the governor of the prefecture or the province over 6-year which. The MAP presents a development program for the presidential mandate. It defines in a detailed manner the program of the municipality, the strategies, and the actions that it carries out for the success of the said project.

The analysis of municipality's MAP of Tangier demonstrates that its elaboration is carried out according to a participative approach that considers the citizen the target of this approach. It is based first of all on a diagnosis of strengths and weaknesses which highlights the needs and potentialities of the municipality to identify projects according to their importance, their coherence with the policies and strategies adopted by the State while respecting the constraints of the means available to the municipality. The projects are subject to an evaluation and monitoring system based on the objectives to be achieved and the related performance indicators. The MAP of Tangier is thus distinguished by a performance-oriented positioning following a strongly convergent approach with a LOLF logic.

Definition of the strategy. Before defining its strategy, the municipality takes an overview of its vision, mission, and values to indicate the main strategic orientations (Figure 3). The municipality's strategy is determined by an internal and external diagnosis of the municipality's environment to select priorities in the form of programs aimed at achieving the required results according to the available means and political orientations. It should be noted that each program is translated in terms of projects which are broken down into actions.

The total cost of the communal program is estimated at 7,216,495,168.00 MAD, which will be allocated to possible sources of financing: self-financing (10\%), public-private partnerships $(48 \%)$, delegated management $(33 \%)$, or borrowing $(8 \%)$. The allocated budget is presented by axis, by the program, and by the project.

This step shows a strong similarity between the municipality and what was recommended by the LOLF. Nevertheless, the definition of the strategy in the municipality differs from the ministerial departments by the co-constructive approach. The communication between elected representatives and citizens/users occurs by the organization of exchanging meetings whose goal is to bring the opinion of citizens and contribute to the elaboration of the communal action plan.

Setting objectives. According to the LOLF, objectives are set based on a triptych dimension, taking into account the citizen, the user, and the taxpayer. As a result, these objectives are subject to the following classification: socio-economic effectiveness objectives, service quality objectives, and efficiency objectives. 


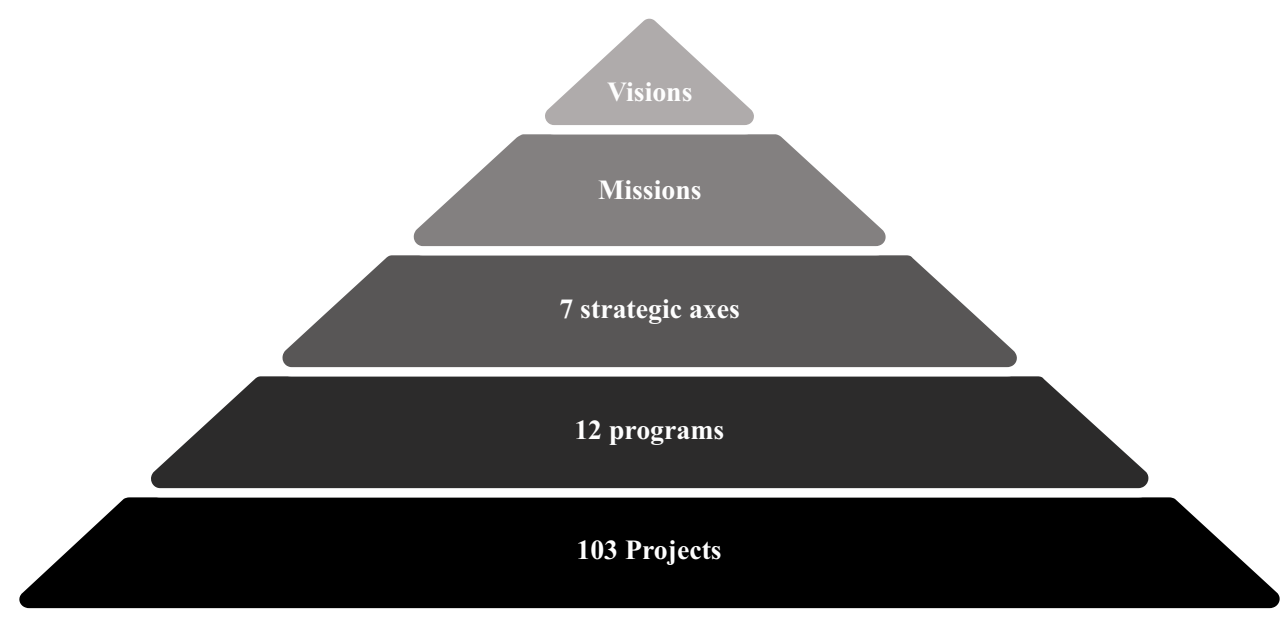

Figure 3. Action program of the municipality of Tangier (source: MAP of the Municipality)

In Tangier municipality, each program is broken down into a set of strategic objectives which are listed hierarchically without being classified according to their typology (socio-economic effectiveness, quality of service, and efficiency). On this basis, some programs may have several objectives but which fall into the same category. It should be noted that, taking into consideration the specificity of local public management, a fourth category can be added, namely objectives linked to the territorial dimension and sustainable development, which are absent according LOLF approach, but which are acutely present in the objectives set by the municipality.

Identification of performance indicator. Program effectiveness is measured through performance indicators that provide a comprehensive overview of the overall progress of the program. In principle, these indicators are determined based on the objectives set. However, according to the MAP, the majority are based on a financial logic by calculating the benefit realization rates, the degree of implementation, and the results of the projects, taking into account the allocated budget, its cost, and its completion time (Table 4).

Table 4. Example of performance indicators adopted by the municipality of Tangier (source: MAP of the Municipality)

\begin{tabular}{|l|l|}
\hline \multicolumn{1}{|c|}{ Type of the indicators } & \multicolumn{1}{c|}{ Calculation method } \\
\hline Indicators of actual project progress & Earned Value Analysis (EVA) \\
\hline $\begin{array}{l}\text { Project Management Effectiveness Indicators: } \\
\text { - Schedule Performance Index (SPI) } \\
\text { - Cost Performance Index (CPI) }\end{array}$ & $\begin{array}{l}\text { Actual Completion Percentage / Scheduled Completion Percentage } \\
\text { Actual Percentage of Expenditures / Actual Expenditures }\end{array}$ \\
\hline
\end{tabular}

The absence of socio-economic indicators measuring the degree of satisfaction of citizens and the degree of impact of policies on the territory calls into question the logic of results-based management and shows that until now, the municipality has reasoned in terms of a logic centered on means.

Reporting. The responsible for each program prepares a report summarizing all the necessary information, which will be sent every two weeks to the Program and Project Management Department. This is an administrative entity in charge of the management, monitoring, and evaluation of all the programs and projects of the municipality. It aims to facilitate all organizational procedures and ensures the smooth running of meetings and the dissemination of reports to the members in charge of the programs, as well as the stakeholders.

At the end of each year, the Project Management Department prepares two annual reports. The first report reflects the progress and results of the programs and projects, while the second report presents an overall assessment of the program. Both reports provide an overall assessment of the Tangier MAP and serve as a basis for decision-making and implementation of future improvements.

The reporting as described and presented by the MAP allowed us to deduce the degree of its similarity with the performance project to which the ministerial departments are committed. However, its purpose in the municipality does not go beyond a simple corrective approach. Indeed, the absence of certain practices such as accountability and benchmarking attest to the fact that it needs to be developed further to match the specificities of the local public context. 


\section{Conclusions}

The debate around public sector performance has been driven by multiple reforms at the international level. In Morocco, the LOLF is the trigger for this transformation, which refers to the beginning of a results-based management approach. Recently, the philosophy, principles, and rules of the LOLF have also been applied in LA even in the absence of an institutional reference framework due to the emergence of an increased need for a performance approach in the local public sphere. However, the question of the transposability of this approach is still relevant. Some authors see no obstacles to its application in LA. In contrast, for others, it could come up against the institutional, organizational, and cultural specificities that characterize the local sphere in comparison to the central or national level.

The study of the municipality of Tangier based on its MAP gave an idea about the performance approach and its application in the local public context. In general, the results of the study show that this approach converges on the LOLF approach. Indeed, the steps, the process, and the name of the approach are the same. However, we deplore the absence of certain practices, namely indicators that measure the effectiveness and impact of territorial public policies on citizens, results-based management in its embryonic phase, and the non-existence of accountability and responsibility. On the other hand, the performance approach here is distinguished by the integration of the territorial and social dimensions, which makes citizen participation essential.

This exploratory study has indeed made it possible to understand some aspects of the performance approach in Moroccan LA. Nevertheless, it does not claim to be exhaustive and does not mean that it lacks certain limitations. Indeed, the choice of a single case does not allow a generalization of the results obtained. This implies that changing the context of the study can immediately lead to changing the results. Hence the necessity to extend the investigation. For that, future and ongoing researches can complete this present paper by enlarging the sample and studying both urban and rural municipalities.

\section{Disclosure statement}

Authors declare no competing financial, professional, or personal interests from other parties.

\section{References}

Amrani, N., Sadik, M., \& Hemmi, M. (2021). Gouvernance des collectivités territoriales au Maroc: Une approche prospective à la lumière des expériences internationales. Alternatives Managériales Economiques, 3(1), 144-165.

Bačlija, I. (2012). Measuring new public management at the local level: Experiences from EU cities. Transylvanian Review of Administrative Sciences, 8(37), 23-37. http://rtsa.ro/tras/

Bezes, P. (2005). Le renouveau du contrôle des bureaucraties. Informations Sociales, 126(6), 26-37. https://doi.org/10.3917/inso.126.0026

Bouckaert, G., \& Halligan, J. (2008). Comparing performance across public sectors. In W. Van Dooren \& S. Van de Walle (Eds.), Performance information in the public sector (pp. 72-93). Palgrave Macmillan UK. https://doi.org/10.1007/978-1-137-10541-7 6

Bourguignon, A. (1995). Peut-on définir la performance? Revue Française de Comptabilité, 269, 61-66.

Calmette, J.-F. (2006). La loi organique relative aux lois de finances (LOLF): Un texte, un esprit, une pratique. Revue Française d'administration Publique, 117(1), 43-55. https://doi.org/10.3917/rfap.117.0043

Denzin, N. K., \& Lincoln, Y. S. (2005). Introduction: The discipline and practice of qualitative research. In The Sage handbook of qualitative research (3rd ed., (pp. 1-32). Sage Publications Ltd.

El Moujahid, L. (2019). Gouvernance et performance des collectivités territoriales au Maroc: cas des communes ciblées par l'INDH au niveau de la province d'ElKelaa des Sraghna [Phd Thesis, Cadi Ayaad University].

ESEC. (2013). Annual report. www.cese.ma

Gagnon, Y. C. (2012). L'étude de cas comme méthode de recherche. PUQ. https://doi.org/10.2307/j.ctv18ph7wf

Haddad. M. (2011). Avantages et opportunités de l'utilisation de la Gestion Axée sur les Résultats (GAR). http://old.cafrad.int

Huteau, S., \& Arthuis, J. (2006). Le management public territorial: Tome 2, Le guide du manager. Editions du Papyrus.

Huteau, S. (2008). La nouvelle gestion publique locale: LOLF et collectivités territoriales. Editeur Le Moniteur.

Issor, Z. (2017). La performance de l'entreprise: Un concept complexe aux multiples dimensions. Projectics / Proyectica / Projectique, 17(2), 93-103. https://doi.org/10.3917/proj.017.0093

Kusek, J. Z., \& Rist, R. C. (2004). Ten steps to a results-based monitoring and evaluation system: a handbook for development practitioners. The World Bank. https://openknowledge.worldbank.org/handle/10986/14926

Marion, A., Asquin, A., Everaere, C., Vinot, D., Wissler, M. (2012). Diagnostic de la performance de l'entreprise - Concepts et méthodes. Dunod. https://doi.org/10.3917/dunod.mario.2012.01

Maurel, C., Carassus, D., Favoreu, C., \& Gardey, D. (2014). Characterization and definition of public performance: An application to local government authorities. Gestion et Management Public, 2(3(1)), 23-44. https://doi.org/10.3917/gmp.023.0023

Mazouz, B., Garzon, C., \& Picard, P. (2012). Les déviances dans les organisations publiques en quête de performance. Vers une gestion prophylactique des risques de déviance. Management international / International Management / Gestiòn Internacional, 16(3), 92-100. https://doi.org/10.7202/1011419ar 
Mazouz, B., \& Leclerc, J. (2008). La gestion intégrée par résultats: Concevoir et gérer autrement la performance dans l'Administration publique. Presses de l'Université du Québec. https://doi.org/10.2307/j.ctv18pgkzv

Newcomer, K., \& Caudle, S. (2011). Public performance management systems: embedding practices for improved success. Public Performance \& Management Review, 35(1), 108-132. https://doi.org/10.2753/PMR1530-9576350106

Notat, N. (2007). Une question centrale. Acteurs de l'Économie, dossier spécial performance.

Pazvakavambwa, A., \& Steyn, G. M. (2014). Implementing results-based management in the public sector of developing countries: what should be considered? Mediterranean Journal of Social Sciences, 5(20), 245. https://doi.org/10.5901/mjss.2014.v5n20p245

Prévost, P., \& Roy, M. (2015). Les approches qualitatives en gestion. Les Presses de l'Université de Montréal. https://doi.org/10.4000/books.pum.2981

Proulx, D., \& Machiavelli, F. (2005). La conception de la gestion par résultats en Amérique latine. Télescope, 12(automne), 42-53.

Rachid, Y., \& Lahmouchi, M. (2019). La gestion axee sur les resultats dans l'administration publique: ou en est le maroc? Finance \& Finance Internationale, 15.

Rubakula, G. (2014). The new public management and its challenges in Africa. Public Policy and Administration Research, 4(4), 85-97.

Saldanha, C. (2002, 5-6 June). Promoting results based management in the public sectors of developing countries. In Paper presented at the Roundtable on Better Measuring, Monitoring and Managing for Results. World Bank, Washington, D.C.

Salgado, M. (2013). La performance: Une dimension fondamentale pour l'évaluation des entreprises et des organisations, 11 . Hal. https://hal.archives-ouvertes.fr/hal-00842219

Salgado, M. (2014). L'évaluation de la performance des entreprises et des établissements publics, 6. Elsevier. https://doi.org/10.1016/j.scad.2014.09.003

Thiétart, R.-A. (2014). Méthodes de recherche en management (4 éd.). Dunod. https://doi.org/10.3917/dunod.thiet.2014.01

Van Helden, G. J., \& Johnsen, A. (2002). A comparative analysis of the development of performance-based management systems in Dutch and Norwegian local government. International Public Management Journal, 5, 75-95.

Walker, R. M., \& Andrews, R. (2015). Local government management and performance: a review of evidence. Journal of Public Administration Research and Theory, 25(1), 101-133. https://doi.org/10.1093/jopart/mut038

Welch, E. W. (2004). Linking citizen satisfaction with e-government and trust in government. Journal of Public Administration Research and Theory, 15(3), 371-391. https://doi.org/10.1093/jopart/mui021

Yin, R. K. T. (2009). Case study research: Design and methods (4th ed.). Sage.

Zahed, M. (2017). La démarche de performance dans la gestion locale: Les collectivités territoriales face aux défis de la nouvelle gouvernance. L'Harmattan. 